\title{
DIFFERENZIAZIONE DI SPECIE IN MYC. TUBERCULOSIS COMPLEX MEDIANTE PCR-RFLP
}

\author{
Paglia M.G.*, De Mori P., Festa A., Nebuloso E.*, \\ Pucillo L.P.,Visca P.* \\ Laboratorio di analisi Chimico-Cliniche e Microbiologia \\ * Unità di Microbiologia Molecolare, I.N.M.I. L. Spallanzani, \\ IRCCS, Roma.
}

I membri del Mycobacterium tuberculosis complex (MTC) sono causa di tubercolosi nell'uomo e negli animali. Essi sono caratterizzati da un elevato grado di identità genetica (99.9\% di similarità a livello nucleotidico).

Questo non consente di utilizzare gli RNA ribosomali (rRNA) o le sequenze spaziatrici interne 16S-23S rRNA (ITS) per l'allocazione tassonomica a livello di specie.

A riguardo, sono stati sviluppati sistemi molecolari alternativi per differenziare le specie appartenenti al complesso MTC: uno dei più recenti è costituito dal gene gyr $\mathrm{B}$ (subunità $\mathrm{B}$ della DNA girasi topoisomerasi II) di Mycobacterium spp (Kasai et al., JCM, 38:301-308), caratterizzato da una elevata variabilità della sequenza nucleotidica.

Scopo del nostro studio è stato quello di valutare il potere discriminatorio di detto gene per differenziare le specie appartenenti al complesso MTC.

Materiali e metodi.

Sono stati utilizzati 25 ceppi di MTC isolati nel periodo gennaio-aprile 2005. I ceppi di riferimento M. tuberculosis H37Rv e M. bovis BCG sono stati impiegati per la messa a punto della PCR-RFLP. Il DNA dei ceppi è stato estratto con QIAamp DNA Mini Kit (Qiagen), previa digestione con lisozima e proteinasi $\mathrm{K}$. Un tratto $(1.020 \mathrm{bp})$ del gene gyrB è stato amplificato con i primers MTUB-f/MTUB-r. I prodotti 
di PCR sono stati digeriti con gli enzimi di restrizione $R s a \mathrm{I}$, TaqI e SacII.

Risultati e Conclusioni.

Dopo digestione enzimatica i ceppi di riferimento hanno mostrato i seguenti profili di restrizione:

\begin{tabular}{lllll}
\hline RsaI & TaqI & SacII & $\begin{array}{l}\text { N. } \\
\text { ceppi }\end{array}$ & $\begin{array}{l}\text { Specie/ } \\
\text { Riferimento }\end{array}$ \\
\hline $555-$ & $450-270-$ & indigerito & 26 & $\begin{array}{l}\text { M. tuberculosis } \\
375\end{array}$ \\
$\begin{array}{llll}130-100- \\
80\end{array}$ & & & H37Rv \\
\hline $470-$ & $450-160-$ & indigerito & 1 & M. bovis \\
375 & $130-105-$ & & & BCG \\
& $100-80$ & & & \\
\hline
\end{tabular}

Tutti gli isolati clinici identificati fenotipicamente come $M$. tuberculosis complex avevano profili identici a quello ottenuto per M. tuberculosis H37Rv e perciò possono essere inclusi nella specie $M$. tuberculosis. In base alla nostra esperienza la PCR-RFLP è una metodica di semplice esecuzione, rapida e a basso costo, ed è attendibile per l'attribuzione di specie tra i membri del complesso MTC. 